e-Journal Al-Syakhsiyyah: Journal of Law \& Family Studies, Vol. 2 No.1 (2020)

(C) Fakultas Syariah IAIN Ponorogo (2020)

Published Online ; Juni 2020

\title{
HISTORISITAS DAN TUJUAN POLIGAMI: PERSPEKTIF INDONESIA DAN NEGARA MUSLIM MODERN
}

\author{
FAHIMUL FUAD
}

UNU Lampung

fahimulfuad80@gmail.com

\begin{abstract}
ABSTRAK : Pembahasan poligami kerap memunculkan perdebatan. Pasalnya, dalam sumber pokok ajaran Islam, poligami hadir dalam bingkai teks hukum yang tidak seragam. Penafsiran dan pemahaman terhadap sumber-sumber teks tersebut pada perkembangannya diberbagai negara muslim juga beragam, tidak terkecuali di Indonesia. Kajian ini bertujuan mengulas tentang pengaturan poligami yang tertuang dalam dinamika perundang-undangan, dengan melihat fakta dan latar sejarah serta tujuan yang hendak dicapai dengan menggunakan pendekatan riset pustaka (library research). Metodologi yang dipakai adalah deskripstif-komparatif, yaitu menggambarkan aturan poligami, baik dari fikih klasik maupun perundangundangan modern. Konteks perundangan-undangan yang dimaksud adalah undangundang Indonesia dan membandingkannya dengan undang-undang Negara muslim lainnya. Penelitian ini diharapakan mampu memberikan pemahaman tentang makna poligami yang lebih berkeadilan, di mana dalam konteks Negara modern, diwujudkan melalui aturan hukum yang bersifat legal dan memiliki daya ikat hukum. Dari hasil kajian yang dilakukan, dapat ditarik benang merah sebagai kesimpulan, Pertama, Poligami dalam fikih dihukumi boleh, dengan jumlah istri maksimal empat orang. Secara normatif, syarat untuk mampu berlaku adil juga diberlakukan dalam perkawinan poligami. Kedua, Seiring perjalanan waktu dan dinamika kehidupan di dalamnya, muncul tuntutan dari kalangan wanita untuk membuat aturan tentang perkawinan, termasuk poligami yang lebih memberi kepastian hukum dan jaminan perlindungan harkat dan martabat kaum wanita. Dari sini, lahirlah UU perkawinan dimana tercakup di dalamnya masalah poligami. Regulasi ini juga mengatur poligami yang harus melalui institusi negara, dimana di dalamnya diterapkan syarat kebolehan poligami yang cukup ketat. Hal yang sama juga diterapkan di beberapa negara muslim modern, seperti Yordania, Mesir, dan Malaysia. Bahkan, Tunisia dan Turki melangkah lebih berani dengan menetapkan larangan poligami. Ketiga, Tujuan adanya aturan poligami dalam bingkai Undang-undang adalah untuk memberikan kepastian hukum, memberikan penghargaan kepada Kaum wanita, dan dalam rangka mengkontekstualisasikan aturan hukum dengan kondisi kekinian, sehingga lebih relevan dan mampu mewujudkan kemaslahatan.
\end{abstract}

Kata Kunci : Sejarah poligami, fiqh perkawinan, perundang-undangan, negara muslim

ABSTRACT : Discussion of polygamy often makes debates. Because, in the main sources of Islamic teachings, polygamy is present in a non-uniform legal text frame. 


\section{HISTORISITAS DAN TUJUAN POLIGAMI: PERSPEKTIF INDONESIA DAN NEGARA MUSLIM MODERN}

Interpretation and understanding of the sources of the text in its development in various Muslim countries are also diverse, not least in Indonesia. This study aims to review the regulation of polygamy as set out in the dynamics of the legislation, by looking at facts and historical settings and objectives to be achieved by using a library research approach. The methodology used is descriptive-comparative, which describes the rules of polygamy, both from classical figh and modern legislation. The context of the law in question is Indonesian law and compares it with the laws of other Muslim countries. This research is expected to be able to provide an understanding of the meaning of polygamy which is more just, where in the context of the modern state, it is realized through legal rules that are legal and have legally binding power. From the results of the study conducted, a red thread can be drawn as a conclusion, First, Polygamy in figh is punishable by, with a maximum of four wives. Normatively, the requirements to be able to apply fairly are also applied in polygamous marriages. Second, Over the course of time and the dynamics of life in them, demands arise from women to make rules about marriages, including polygamy which gives more legal certainty and guarantees the protection of the dignity of the people woman. From this, the marriage law was born which covered the issue of polygamy. This regulation also regulates polygamy which must go through state institutions, in which the requirements for polygamy permits are quite strict. The same thing is also applied in several modern Muslim countries, such as Jordan, Egypt and Malaysia. Tunisia and Turkey stepped bolder by establishing a ban on polygamy. Third, the purpose of the existence of polygamy rules in the framework of the Act is to provide legal certainty, give respect to women, and to contextualize the rule of law with current conditions, so that it is more relevant and able to realize a benefit.

Keywords: History of polygamy, marriage figh, legislation, Muslim countries

\section{PENDAHULUAN}

Perkawinan merupakan satu hal yang bersifat qodrati. Kebutuhan akan teman intim, penyaluran hasrat biologis hingga keinginan untuk memiliki keturunan, merupakan faktor pendorong lahirnya perkawinan. Lebih jauh, Al-Qur'an menggariskan adanya perkawinan sebagai sarana untuk mendapatkan kebahagiaan hidup dalam wujud ketentraman jiwa dan kasih sayang1. Semua keinginan mulia ini dapat terwujud melalui adanya perkawinan. Oleh karena itu, di sisi lain, al-Qur'ān menyebut ikatan perkawinan sebagai satu ikatan yang kokoh dan agung (misàqan Galị̣a)', dan masing-masing pribadi yang terikat dalam bingkai perkawinan wajib menjaganya dengan sungguh-sungguh sehingga tercapai tujuan hakiki dari perkawinan.

Al-Qur'an dan Sunnah sebagai dua sumber pokok ajaran Islam, juga menyediakan dalil yang lengkap mengenai hukum perkawinan. Dalil-dalil tersebut lantas dielaborasi sedemikian rupa oleh para mujtahid hingga menghasilkan fikih dalam bidang perkawinan yang dikenal sebagai fikih

\footnotetext{
${ }^{1}$ Kementrian Agama RI, Al-Qur'an dan Tafsirnya, Jilid VII, (Jakarta: Lentera Abadi, 2010), hlm. 483.

${ }^{2}$ Lihat, QS. An-Nisa' ayat 21.
} 


\section{HISTORISITAS DAN TUJUAN POLIGAMI: PERSPEKTIF INDONESIA DAN NEGARA MUSLIM MODERN}

munakahat. Fikih munakahat, dengan demikian, merupakan bidang fikih yang menguraikan persoalan nikah, talak, rujuk, dan pengasuhan anak. Dalam persoalan nikah, tertuang banyak ketentuan termasuk diantaranya berkait dengan poligami.

Pembahasan poligami kerap memunculkan perdebatan. Pasalnya, dalam sumber pokok ajaran Islam, poligami hadir dalam bingkai teks hukum yang tidak seragam. Penafsiran dan pemahaman terhadap sumber-sumber teks tersebut pada gilirannya juga beragam. Terlebih lagi, kondisi masyarakat kekinian yang sudah mengalami pergeseran dalam banyak hal, menjadi pemicu lahirnya keinginan untuk 'membaca ulang' ketentuan mengenai poligami. Isu kesetaraan dan keadilan juga turut memantik perdebatan tentang poligami, baik pada ranah fikih maupun Undang-undang Negara. Sebagai contoh, poligami yang dalam wacana klasik dimaknai sebagai 'hak' laki-laki dalam menambah jumlah istri, tanpa ada syarat yang bersifat pasti dan mengikat, kini dimunculkan dengan aturan yang lebih pasti, terukur, dan memiliki daya ikat hukum. Tujuannya tentu dalam rangka lebih menghargai posisi dan peran perempuan dalam konteks perkawinan.

Kajian ini mengulas aturan poligami yang tertuang dalam dinamika perundang-undangan, dengan melihat fakta dan latar sejarah serta tujuan yang hendak dicapai. Konteks perundangan-undangan yang dimaksud adalah undang-undang Indonesia dan membandingkannya dengan undangundang Negara muslim lainnya. Sebagai landasan kajian, Pembahasan dimaksud diawali dengan menghadirkan perbincangan tentang poligami dalam kajian fikih.

\section{Poligami dalam Wacana Fikih}

Ibn Rusyd, seorang ulama Mazhab Maliki, mengatakan bahwa umat Islamsepakat mengenai kebolehan menikahi lebih dari seorang wanita, sampai batas maksimal 4 orang wanita ${ }^{3}$. Kebolehan 4 ini merupakan makna tersurat dari firman Allah Swt.dalam surat an-Nisa' ayat 3, yaitu:

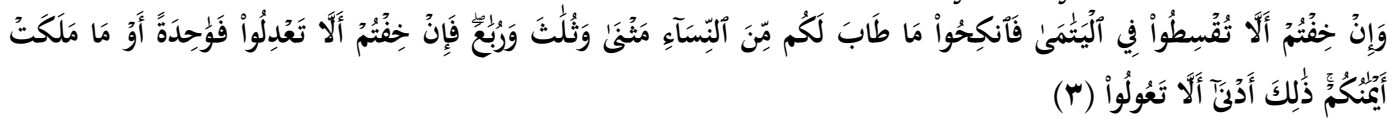

Artinya: "Dan jika khawatir tidak akan mampu berlaku adil terhadap (hak-hak) perempuan yatim (bila kamu menikahinya), maka nikahilah perempuan (lain) yang kamu senangi: dua, tiga atau empat. Tetapi jika kamu khawatir tidak akan mampu

\footnotetext{
${ }^{3}$ Ibn Rusyd al-Qurtubī, Bidāyatul-Mujtahid wa Nihāyatul-Muqtasid, Juz II, (Ttp: Dar Ihya' al Kutub al-'Arabiyyah, tt), hlm. 31.

4 Boleh dalam arti ini merujuk kepada makna jawaz atau ibahah/ mubah, yang berarti boleh, bukan anjuran apalagi kewajiban. Mubah/ibahah sendiri merupakan satu di antara lima ketentuan hukum taklify, sebagaimana dikenal dalam ushul fikih, yaitu wajib, sunah, mubah, makruh dan haram. Lihat, Abdul Wahab Khallaf, 'Ilm Ușül al-Fiqh, (Kuwait: Dar al ‘Ilm, 1978), hlm. 105.
} 


\section{HISTORISITAS DAN TUJUAN POLIGAMI: PERSPEKTIF INDONESIA DAN NEGARA MUSLIM MODERN}

berlaku adil, maka nikahilah seorang saja, atau hamba sahaya perempuanyang kamu miliki.Yang demikian itu lebih dekat, agar kamu tidak berbuat Zalim". 5

Berdasarkan ayat di atas, hukum poligami adalah boleh. Boleh dalam arti ini merujuk kepada makna jawāz/mubāh untuk membedakannya dengan sunnah (anjuran) atau wajib (perintah). Meskipun secara eksplisit redaksi kalimat dalam ayat di atas menggunakan șigat 'amr (kata perintah), yang itu biasanya merujuk kepada makna wajib, namun rangkaian kalimat pada lanjutan ayat tersebut menyebutkan adanya Qarinah yang membelokkan makna wajib dalam redaksi 'amr kepada makna sunnah.

Jumhur ulama sepakat bahwa batas maksimal dalam poligami adalah dengan empat orang wanita, jika lebih dari itu, lima misalnya, maka yang demikian tidaklah diperbolehkan. Meski demikian, ada sekelompok kecil golongan yang membolehkan poligami dengan jumlah wanita lebih dari empat, yaitu sampai batas angka sembilan. Mereka berpendapat dengan memahami redaksi ayat yang menggunakan kata sambung waw (و) dengan makna 'dan' yang itu berarti menjumlahkan, sehingga menghasilkan angka sembilan ${ }^{6}$.

Menurut az-Zamakhsyari sebagaimana dikutip olehAș-Ṣābūnī pemahaman yang menghasilkan angka sembilan dalam konteks poligami adalah pemahaman yang tidak dapat dibenarkan dari sisi kaidah bahasa. Senada dengan ini, pendapat yang disampaikan oleh Imam al-Qurtubi, bahwa pemahaman yang menghasilkan angka di atas jumlah 4, merupakan pemahaman yang keliru dan jauh dari maksud syariat ${ }^{7}$.

Imam As-Suyūti ketika men-syarahi kitab al-Muwatta' karya Imam Malik, menuangkan satu hadis yang secara jelas memberikan batasan poligami hanya dengan maksimal empat wanita. Dari Yahya, dari Malik dari Ibnu Syihab, bahwa ada informasi yang sampai kepada beliau dimana Rasulullah Saw.bersabda kepada seorang laki-laki dari Qabilah $\dot{S} a q i b$ yang masuk Islam, dimana ia memiliki sepuluh istri. Kata Rasul ambillah empat orang di antara mereka, dan ceraikan selebihnya ${ }^{8}$.

$$
\text { أسلم غيلان الثقفي وعنده عشر نسوة في الجاهلية فأسلمن معه ، فأمره النبي صلى الله عليه وسلم أن يختار منهن أربعا. }
$$

5 Dalam riwayat Imam Bukhori, Aisyah mengabarkan mengenai asbabun nuzul ayat ini bahwa ada seorang gadis yatim yang berada dalam asuhan walinya. Ia berserikat dengan walinya dalam hal harta benda. Saat tiba waktunya, si wali tertarik kepada gadis yatim tersebut dan bermaksud menikahinya, tanpa meberikan mahar yang layak. Maka turunlah ayat tersebut. Lihat,Kemenag RI, Op. Cit., Jilid II, hlm. 115.

${ }^{6}$ Ibn Rusyd al-Qurtubi, Op. Cit.

${ }^{7}$ Muhammad Ali Às Ṣābūnī, Tafsir Ayat al Ahkam min Al-Qur'an, Juz I, (Ttp: Tnp, tt), hlm. 303.

${ }^{8}$ As-Suyūti, Tanwīr al Hạâwalik, Syarh 'ala Muwatta' Malik, Juz II, (Ttp: Tnp, tt), hlm. 102-103; lihat pula Ibnu Hajar al-'Asqalanī, Bulügh al Marām min Adillat al Ahkam, (Ttp: Tnp, tt), hlm. 217. 


\section{HISTORISITAS DAN TUJUAN POLIGAMI: \\ PERSPEKTIF INDONESIA DAN NEGARA MUSLIM MODERN}

Secara lugas hadis di atas menyebutkan bahwa diantara sepuluh istri yang dimiliki, Rasul hanya mengizinkan empat diantaranya untuk tetap menjadi istri. Sedangkan sisanya diminta untuk diceraikan. Hadis ini mengukuhkan kandungan ayat sebagaimana telah disebutkan, sekaligus menjadi hujjah kalangan Jumhur ulama tentang batas maksimal poligami.

Di samping hadis di atas, Aș-Ṣan'anī juga mengemukakan satu hadis mengenai Naufal Ibn Mu'awiyah yang masuk Islam dan pada saat itu ia memiliki lima orang istri. Kemudian ia bertanya kepada Rasulullah Saw.dan Rasul menjawabnya dengan mengatakan:

$$
\text { أسلمت وتحتي خمس نسوة فقال النبي صلى الله عليه وسلم: "فارق واحدة منهن وأمسك أربعاً. }
$$

"Aku masuk Islam, dan memiliki lima orang istri. Lalu, Nabi SAW bersabda: ceraikan satu, dan ambillah empat diantaranya"9.

Hadis ini, dengan demikian, makin mengukuhkan akan batas maksimal jumlah istri yang boleh dipoligami dalam satu ikatan pernikahan, yaitu empat orang wanita.

Namun demikian, kebolehan hukum poligami bukanlah ketentuan yang tanpa syarat. Rangkaian ayat al-Qur'an dalam surat an-Nisa' ayat 3 di atas, secara tersurat pula menegaskan bahwa jika sang suami tidak dapat berlaku adil, maka cukuplah menikahi satu orang wanita saja.

Kriteria adil menjadi kata kunci yang disampaikan al-Qur'an kepada mereka yang hendak melakukan perkawinan secara poligami. Keadilan yang dimaksud mencakup keadilan dalam kaitan pembagian waktu bermalam (giliran), nafkah, perumahan serta hal-hal yang berbentuk materi lainnya ${ }^{10}$. Ini untuk memastikan agar poligami yang ada tidak justru menjurumuskan masing-masing pihak kepada kondisi yang menyusahkan, oleh karena tidak didasari oleh kemampuan yang cukup khususnya dari sisi materinya.

Tuntutan harus berbuat adil tethadap para istri, menurut asy-Syafi'i sebagaimana dikutip oleh Khoirudin Nasution, adalah keadilan yang berhubungan dengan masalah fisik, misalnya mengunjungi istri di siang atau malam hari11. Berkait dengan ini, dalam fikih disebutkan bahwa berbuat adil dalam hal giliran terhadap para istri merupakan satu hal yang berhukum wajib. Seorang suami tidak boleh mendatangi seorang istri yang bukan waktu gilirnya, kecuali bila ada hal yang mendesak. Demikian pula, jika sang suami hendak bepergian, ia harus mengundi di antara para istrinya, dan bagi istri yang namanya keluar dalam undian akan pergi menemani sang suami ${ }^{12}$.

Ibn Rusyd juga nenegaskan bahwa seorang suami yang memiliki istri lebih dari satu, wajib berbuat adil dalam hal giliran (qismah). Ketentuan ini

${ }^{9}$ Muhammad Ibn Ismail Aṣ-Șan’ani, Subul as-Salām, Juz III, (Surabaya: Al Hidayah, tt), hlm. 132 .

${ }^{10}$ Kementrian Agama RI, Op. Cit., Jilid II, hlm. 115.

${ }^{11}$ Khoiruddin Nasution,Hukum Perdata (Keluarga) Islam Indonesia dan Perbandingan Hukum Perkawinan di Dunia Muslim, (Yogyakarta: ACAdeMIA\&Tazzafa, 2013), hlm. 266.

${ }^{12}$ Abi Syuja', At-Taqrīb, (Ttp: Tnp, tt), hlm. 46-47. 
merupakan kesepakatan semua Mazhab. Menguatkan pernyataannya ini, Ibn Rusyd mengutip sunnah filiyyah nabi Saw. yang senantiasa berbuat adil dalam hal gilir kepada para istrinya. Dalam hal ini, terdapat satu riwayat dari 'Aisyah RA, bahwa Rasulullah Saw. membagi waktu gilir untuk para istrinya dan berusaha berbuat adil. Lantas beliau berdoa; "Ya Allah, inilah penggiliranku sesuai dengan kemampuanku, maka janganlah Engkau mencelaku terhadap apa yang Engkau kuasai, tetapi aku tidak menguasai ${ }^{13}$. Lebih lanjut, terdapat pula sunnah qauliyyah dimana Rasul bersabda:

$$
\text { من كان له امرأتان فمال إلى إحداهما جاء يوم القيامة وشقّه مائل. }
$$

"Jika ada seorang laki-laki memiliki dua istri, lantas ia lebih condong kepada salah satu diantara keduanya, maka pada hari kiamat ia akan datang dalam kondisi tubuh yang miring/tidak seimbang"14.

Selanjutnya, keadilan seorang suami terhadap para istrinya juga berlaku dalam hal nafkah berupa penghidupan yang layak menyangkut sandang, pangan dan papan ${ }^{15}$. Sebab, seorang suami mempunyai kewajiban untuk memberikan nafkah kepada istri dan anaknya secara layak. Hal ini sejalan dengan firman Allah Swt., yang Artinya: "Dan kewajiban ayah menanggung nafkah dan pakaian mereka dengan cara yang patut (makruf)".

Berdasar ayat di atas, ulama sepakat bahwa hukum memberikan nafkah dari suami kepada istri dan anaknya adalah wajib. Sejalan dengan ayat di atas, Rasul pernah bersabda: "Dan menjadi hak para istri atas kalian (para suami) untuk mendapatkan nafkah dan pakaian secara layak". Demikian pula, diriwayatkan Rasul pernah berkata kepada Hindun: "Ambillah apa yang mencukupkan dirimu dan anakmu secara layak"16. Dengan demikian, jika seorang suami memiliki istri lebih dari seorang, maka ia harus mampu berbuat adil kepada para istri dan juga anak-anaknya dalam segala hal yang berkait nafkah.

Meski adil menjadi kata kunci dalam pernikahan poligami, namun praktek keadilan yang disyaratkan lebih menitikberatkan adil dalam arti fisik-material. Artinya, cakupannya sebagaimana yang telah diuraikan berkisar pada keadilan dalam giliran dan nafkah lahir berupa sandang, pangan dan papan. Adapun adil yang hakiki dalam arti keadilan secara bathiniyyah berupa kecenderungan psikologis, al-Qur'an memberikan 'kelonggaran' untuk mengupayakannya sesuai batas kemampuan. Allah SWT berfirman:

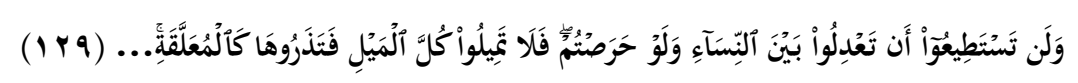

${ }_{13}$ Kementrian Agama RI, Op. Cit., Jilid II, hlm. 286; Hadis ini diriwayatkan oleh Imam Ahmad dan penyusun kitab-kitab Sunan.

${ }^{14}$ Ibn Rusyd al-Qurtubi, Op. Cit., Juz II, hlm. 42 .

${ }^{15}$ Kementrian Agama RI, Op. Cit.

${ }^{16}$ Ibn Rusyd al-Qurtubī, Op. Cit., hlm. 40-41. 


\section{HISTORISITAS DAN TUJUAN POLIGAMI: \\ PERSPEKTIF INDONESIA DAN NEGARA MUSLIM MODERN}

Artinya: "Dan kamu tidak akan dapat berlaku adil diantara istri-istrimu, walaupun kamu sangat ingin melakukan yang demikian, karena itu janganlah kamu terlalu cenderung (kepada yang kamu cintai), sehingga kamu biarkan yang lain terkatung-katung".

Dari ayat ini, dapat dipahami bahwa manusia tidak dapat menguasai hatinya sendiri, untuk berlaku adil secara paripurna: luar dan dalam. Meskipun ia sangat ingin melakukannya, namun keterbatasan manusiawi juga yang membuatnya tetap memiliki 'rasa yang tidak sama' terhadap para istrinya ${ }^{17}$.

Hal yang demikian tidaklah mengapa, sepanjang ia telah berupaya sekuat tenaga. Yang terpenting adalah, jangan sampai rasa cinta yang tidak sama tadi, membuatnya menelantarkan istrinya yang lain, hingga ia hidup merana, terkatung-katung dan jauh dari rasa nyaman ${ }^{18}$.

\section{Aturan Poligami dalam Konteks Indonesia}

\section{Fakta Sejarah}

Secara umum, wacana tentang masuknya ajaran Islam secara formal ke dalam 'wilayah' negara telah mengemuka sejak lahirnya negeri ini. Awal pembentukan negara yang diwarnai tarik ulur kepentingan mengenai bentuk dan dasar negara menunjukkan adanya upaya-upaya formalisasi Islam dalam ranah negara. Jika kemudian pilihan jatuh kepada bentuk Negara Pancasila, hal ini tidaklah berarti memadamkan semangat kelompok formalisme agama. Mereka terus berjuang dengan caranya, terutama pasca Reformasi. Namun demikian, kelahiran UU No. 1 Tahun 1974 dan KHI tidak berarti merupakan upaya formalisme sebagaimana tuntutan kelompok fundamentalis. Hal ini karena dalam beberapa hal terdapat perbedaan fundamental antara kelahiran aturan normatif ini, dengan tuntutan dan mindset mereka ${ }^{19}$.

Berkait dengan adanya hukum mengenai perkawinan dan secara umum tentang keluarga, telah mengemuka sejak lama. Secara kultur, muncul beberapa tokoh khususnya dari kalangan wanita yang menyuarakan kritik terhadap aturan perkawinan yang dalam banyak sisi cenderung deskriminatif. Tersebut nama RA Kartini dari Jawa Tengah dan Rohana

\footnotetext{
${ }^{17}$ Persoalan rasa yang mewujud dalam kata cinta (hubb) adalah sesuatu yang tidak bias diukur. Oleh karenanya, menjadi mustahil untuk dapat menakar secara sama rata rasa cinta terhadap para istrinya. Karena itulah, ketentuan adil yang ditetapkan diwujudkan dalam bentuk yang terukur, bukan yang tidak terukur. Lebih jauh, fikih sendiri merupakan aturan yang berkait dengan sesuatu yang berdimensi Zahir, bukan dimensi Batin. Lihat, 'Izz ad Din Ibn 'Abd as-Salam, Qawa'id al-Ahkam fi Masalih al Anam, Jzz I, (Beirut: Dar al-Kutub al-Ilmiyyah, 1999), hlm. 51.

18 Kementrian Agama RI, Op. Cit., hlm. 286-287

${ }^{19}$ Baca, M. Ali Haidar, Nahdlatul Ulama dan Islam di Indonesia, Pendekatan Fikih dalam Politik, (Jakarta: Gramedia, 1998), cet. ke- 2, h. 3-7; Marzuki Wahid dan Nurrohman, Dimensi Fundamentalisme dalam Politik Formalisasi Syari'at Islam, Kasus NAD, dalam Taswirul Afkar, Edisi No. 13 Tahun 2002, h. 34-37; Abdurahman, Kompilasi Hukum Islam, (Jakarta: Akademika Pressindo, 2007), cet. ke- 5, h. 2-4.
} 


\section{HISTORISITAS DAN TUJUAN POLIGAMI: PERSPEKTIF INDONESIA DAN NEGARA MUSLIM MODERN}

Kudus dari Minangkabau, yang mengemukakan kritik tentang munculnya keburukan-keburukan akibat dari praktik perkawinan paksa, di bawah umur, pola perceraian yang sewenang-wenang, dan juga poligami ${ }^{20}$.

Pada persoalan yang lebih khusus, yaitu tentang poligami, terdapat pertemuan kalangan wanita yang tergabung dalam organisasi Puteri Indonesia, bekerjasama dengan Persaudaraan Isteri, Persatuan Isteri dan Wanita Sejati, pada tanggal 13 Oktober 1929 yang menghasilkan ketetapan mengenai larangan poligami. Hasil ketetapan ini dibicarakan bersama dengan tema yang lain, yaitu mengenai pelacuran. Selanjutnya, pada bulan Juni 1931, dilaksanakan pula Kongres Isteri Sedar yang menghasilkan keputusan menguatkan larangan poligami. Rentetan perjuangan kelembagaan ini, pada gilirannya memberikan dorongan kepada pemerintah Hindia Belanda waktu itu untuk merumuskan Rancangan Ordonansi Perkawinan Tercatat dengan mengakomodir 'seruan' kaum wanita tersebut. Salah satu yang kemudian muncul adalah adanya prinsip mongami dalam perkawinan, dan larangan menjatuhkan talak di luar pengadilan ${ }^{21}$.

Masa Orde Lama sebagai awal pemerintahan Indonesia, meski tidak banyak ${ }^{22}$, juga memberikan respon akan pentingnya UU tentang perkawinan. Secara resmi pemerintah Indonesia merintis lahirnya UU tentang perkawinan dengan membentuk sebuah Panitian Penyelidik Peraturan dan Hukum Perkawinan, Talak dan Rujuk dengan dasar keluarnya surat Menteri Agama No. B/2/4299, tertanggal 1 Oktober $1950^{23}$.

Dalam perjalanannya, Panitia ini melakukan kajian dalam rangka meninjau seluruh aturan tentang Perkawinan yang pernah ada, dan berhasil membuat rancangan Undang-undang yang dinilai lebih sesuai dengan perkembangan zaman. Namun, seiring gejolak politik yang terjadi, RUU ini tak berhasil disahkan karena lembaga legislatif yang seyogyannya mengesahannya, dibekukan lewat Dektrit Presiden tahun 1959. Namun demikian, masih terdapat upaya-upaya untuk terus mengawal lahirnya UU Perkawinan, lewat beberapa pertemuan penting yang membicarakan masalah hukum perkawinan dan perundang-udangannya ${ }^{24}$.

Pada masa Orde Baru, upaya untuk melembagakan aturan tentang perkawinan dalam bentuk undang-undang Perkawinan terus dilaksanakan. Pada TAP MPRS No. XXVIII/MPRS/1966, tersebut ayat I pasal (3) yang

${ }^{20}$ Khoiruddin Nasution, Op. Cit., hlm. 27-28.

${ }^{21}$ Ibid., hlm. 28-29.

22 Pada masa ini lahir UU N0. 22 tahun 1946 yang pemberlakuannya diperluas lewat UU No. 32 tahun 1954 tentang Pencatatan Nikah, Talak dan Rujuk. Ibid., hlm. 31.

${ }^{23}$ Ibid., hlm. 35.

24 Pertemuan-pertemuan dimaksud adalah: (1). Musyawarah Nasional Kesejahteraan Keluarga tahun 1960; (2) Konferensi Badan Penasehat Perkawinan dan Penyelesaian Perceraian (BP4) Pusat yang diselenggarakan oleh Departemen Agama tahun 1962; (3)Seminar Hukum Nasional yang diselenggarakan oleh Lembaga Pembinaan Hukum Nasional (LPHN) bersama Persatuan Sarjana Hukum Indonesia (Persahi) tahun 1963. Ibid., hlm. 37. 
mentakan bahwa perlu segera diadakan undang-undang tentang Perkawinan. Semangat dari TAP MPRS tersebut, maka secara faktual pada tahun 1967 dan 1968, pemerintah mengajukan dua rancangan undangundang berkait dengan Perkawinan kepada DPR-GR, yaitu RUU tentang pernikahan umat Islam, dan RUU tentang ketentuan Pokok Perkawinan. Namun, kedua RUU tersebut tidak mendapat persetujuan dari lembaga Legislatif, oleh karena ada fraksi yang menolak RUU tersebut.

Sementara itu, desakan akan lahirya UU Perkawinan semakin menguat ${ }^{25}$. Ini dilakukan oleh lembaga dan organisasi-organisai wanita yang tetap menginginkan lahirnya undang-undang entang Perkawinan dalam rangka mewujudkan kepastian hukum di bidang Perkawinan. Ikatan Sarjana Wanita Indonesia (ISWI) misalnya, dalam satu simposium di tanggal 29 Januari 1972 memberikan catatan penting bahwa makain dirasakan mendesaknya akan keperluan sesuatu UU Perkawinan untuk Indonesia. Badan Musyawarah Organisasi-organisai Wanita Indonesia juga mendesak pemerintah agar mengajukan kembali dua RUU yang pernah tidak disetujui oleh DPR-GR kepada DPR hasil pemilu $1971^{26}$.

Atas dorongan dari berbagai pihak, akhirnya setelah berupaya keras, pemerintah dapat menyiapkan sebuah RUU baru. RUU ini selanjutnya diajukan kepada DPR untuk dibahas dan disahkan pada tanggal 31 Juli 1973. RUU yang baru ini mempunyai 15 bab dan 73 pasal. Pembahasan mengenai RUU ini diwarnai dengan perdebatan, kontroversi dan adu argumentasi yang sengit. Masing-masing fraksi memberikan gambaran dan pandangan yang beragam. Ada kesepakatan, tarik ulur pendapat, hingga revisi-revisi. Di luar gedung parlemen, tak kalah panas. Banyak massa yang melakukan demonstrasi menentang bahkan mengutuk pembahasan mengenai RUU tersebut, dan menganggapnya sebagai upaya sekulerisasi. Pada akhirnya, RUU tentang hukum Perkawinan tersebut, setelah melalui proses yang demikian panjang, berhasil disahkan dan diundangkan pada tanggal 2 Januari 1974. Meski demikian, pemberlakuannya secara efektif baru dimulai pada 1 Oktober $1975^{27}$.

\section{Poligami dalam UU NO. 1/1974 dan KHI}

Pada dasarnya, asas perkawinan Islam sebagaimana tertuang dalam Undang-undang No. 1 Tahun 1974 adalah monogami/monogini, yaitu seorang suami hanya memiliki seorang istri, demikian pula sebaliknya.

${ }^{25}$ Dalam catatan Bustanul Arifin, dekade 1970-an menampakkan gejala global pada dunia hukum. Pada masa itu, banyak Negara yang mencoba menyusun aturan-aturan hukum berkait dengan Perkawinan, dan secara umum tentang keluarga. Menyebut beberapa contoh, gejala ini terjadi di Belanda pada tahun 1971, dan tahun 1975 di Australia. Bustanul Arifin, Pelembagaan Hukum Islam di Indonesia, Akar Sejarah, Hambatan dan Prospeknya. (Jakarta: Gema Insani Press, 1996), hlm. 118.

${ }^{26}$ Khoiruddin Nasution, Op. Cit., hlm. 39.

${ }^{27} \mathrm{Hal}$ demikian karena diperlukan langkah-langkah persiapan dan serangkaian petunjuk pelaksanaan dari berbagai Instansi/ Departemen terkait, khususnya Departemen Agama, Kehakiman dan Departemen Dalam Negeri.Ibid., hlm. 51. 


\section{HISTORISITAS DAN TUJUAN POLIGAMI: \\ PERSPEKTIF INDONESIA DAN NEGARA MUSLIM MODERN}

Dalam UU No.1/ 1974 dinyatakan: "Pada asasnya, dalam suatu perkawinan seorang pria hanyaboleh mempunyai satu istri. Seorang istri hanya boleh mempunyai seorang suami"28. Namun demikian, ini tidak berarti menutup kemungkinan bagi seorang suami untuk memiliki lebih dari seorang istri. Kemungkinan berpoligami tetap ada, dengan syarat poligami yang dilakukan didasarkan atas izin dari Pengadilan, dimana salah satu syaratnya adalah mendapat persetujuan dari istrinya. Dengan demikian, poligami bukanlah sebuah anjuran, namun juga bukan sebuah larangan. Poligami adalah sebuah kebolehan, dengan memperhatikan dan mempertimbangkan syaratsyaratnya sebagaimana tertuang dalam UU Perkawinan. Hal kebolehan poligami ini, sejalan dengan pendapat Ulama fikih sebagaimana telah diuraikan.

Selanjutnya, kebolehan akan poligami juga dibatasi dengan jumlah istri maksimal empat (4) orang dalam satu ikatan perkawianan. Dalam hal ini, KHI menyatakan: "Beristri lebih dari satu orang, pada waktu yang bersamaan terbatas hanya sampai empat orang istri"29. Pada prakteknya, jika seorang suami hendak melakukan poligami, maka ia harus mendapatkan izin dari pengadilan di tempat ia tinggal. Selanjutnya, pengadilan akan melihat dan menilai apakah pengajuan poligami dapat dikabulkan atau tidak. Secara normatif, pemberian izin poligami didasarkan atas pertimbangan kondisi istri yang mengalami kondisi-kondisi berikut ${ }^{30}$ :

a. Istri tidak dapat menjalankan kewajibannya sebagai istri

b. Istri mendapat cacat badan atau penyakit yang tidak dapat disembuhkan

c. Istri tidak dapat melahirkan keturunan.

Di samping kondisi di atas, seorang suami boleh mengajukan permohonan poligami apabila memenuhi syarat sebagai berikut ${ }^{31}$ :

a. Ada persetujuan dari istri/ istri-istri

b. Adanya kepastian bahwa suami mampu menjamin keperluan hidup istriistri dan anak-anaka mereka.

c. Adanya jaminan bahwa suami akan berlaku adil terhadap istri-istri dan anak-anak mereka.

Ketentuan dalam UU Perkawinan ini memberikan penegasan dankepastian akan jaminan banyak hal, yang mencakup kemampuan fisik, dan finansial, baik untuk istri maupun anak-anaknya. Kepastian akan kemampuan sang suami juga harus ditopang dengan kondisi psikisnya yang mapan, sehingga mampu berlaku adil terhadap semua istri-istri dan anakanaknya.

\footnotetext{
${ }^{28}$ Lihat UU No. 1 Tahun 1974 Pasal 3 ayat (1).

${ }^{29}$ Lihat, KHI Pasal 55 (ayat) 1.

${ }^{30}$ UU No. 1 Tahun 1974 Pasal 4 (ayat) 2.

${ }^{31}$ UU No. 1 Tahun 1974 Pasal 5 (ayat) 1.
} 


\section{Aturan Poligami di Beberapa Negara Muslim Modern.}

Persoalan aturan tentang poligami, ternyata juga menyeruak di hampir semua Negara Muslim Modern. Meski dengan latar sejarah yang tidak persis sama, namun adanya tuntutan lesgislasi dalam hal poligami mengerucut kepada upaya menciptakan kepastian hukum yang dilatarbelakangi oleh tuntutan pengakuan akan harkat dan martabat kaum wanita.

Beberapa negara Muslim yang merupakan tetangga Indonesia, yakni di kawasan Asia Tenggara juga telah memiliki dan menerapkan aturan tentang poligami. Malaysia dalam UU Perkawinan-nya tidak secara tegas menyebutkan asas perkawinannya sebagai monogami. Hal ini memberikan ruang pemahaman bahwa perkawinan poligami adalah boleh. Hanya saja, secara normatif, Malaysia mengharuskan pencatatan secara admnistratif terhadap semua hal berkaitan dengan perkawinan, termasuk kaitan poligami. Perkawinan poligami akan diizinkan dengan melihat aspek-aspek yang berkait dengan suami dan istri. Hal-hal yang terkait dengan istri adalah: (i) kemandulan, (ii) uzur jasmani, (iii) secara jasmani tidak layak untuk bersetubuh, (iv) tidak mau melayani suami dengan sengaja, dan (v) istri dalam kondisi gila. Adapun pihak suami akan dilihat dari aspek berikut: (i) mampu secara ekonomi untuk mencukupi kebutuhan istri-istri dan anakanaknya, (ii) berusaha untuk berbuat adil, (iii) poligami yang dilakukan tidak menumbulkan madlarat/bahaya terhadap istri sebelumnya dari sisi agama, jiwa, badan, dan harta, serta (iv) poligami tersebut tidak menurunkan martabat istri dan keluarganya. Seorang suami yang melakukan perkawinan poligami dengan tanpa mengikuti prosedur yang ditetapkan, maka ia akan terkena sanksi berupa denda atau penjara atau kedua-duanya sekaligus ${ }^{32}$.

Brunei Darussalam, dalam UU perkawinannya tidak mencantumkan persoalan poligami. Jika terjadi praktek poligami hanya terdapat anjuran untuk tidak dilakukan secara sembarangan, namun harus dengan penuh pertimbangan. Namun, karena bukan merupakan Undang-undang, maka hakim atau pengadilan tidak dapat melarang poligami, dan tugas pengadilan sebatas anjuran agar suami tidak menelantarkan istri dan anak-anaknya ${ }^{33}$.

Secara normatif, Singapura juga tidak memiliki aturan khusus tentang poligami. Hanya saja, dalam praktik perkawiannya, semua syarat harus terpenuhi dimana salah satunya menetapkan bahwa seorang laki-laki yang telah mempunyai istri tidak boleh melangsungkan perkawinan, kecuali mendapat izin dari hakim. Dan pada prakteknya hakim tidak akan memberikan izin untuk perkawinan poligami ${ }^{34}$.

Yordania tidak memiliki aturan yang secara tegas mengatur tentang poligami. Namun demikian, secara tersirat terdapat ketentuan dalam pasal 17 Undang-undang perkawinan Yordania yang menyatakan bahwa suami yang

\footnotetext{
${ }^{32}$ Khoiruddin Nasution, Op. Cit., hlm., 276-282.

${ }^{33}$ Ibid., hlm. 284-285.

${ }^{34}$ Ibid., hlm. 285-286.
} 


\section{HISTORISITAS DAN TUJUAN POLIGAMI: PERSPEKTIF INDONESIA DAN NEGARA MUSLIM MODERN}

berpoligami dilarang mencampurkan istri-istrinya di dalam satu rumah. Ketentuan ini menyiratkan kebolehan akan poligami bagi seorang suami. Secara teknis, poligami dimaksud tetap melibatkan peran pengadilan agama (mahkamah shari'ah), dimana seorang istri diberikan kesempatan untuk mengajukan keberatan dan pembatalan terhadap pernikahan poligami suaminya. Jauh sebelumnya, seorang istri dalam akad nikah juga diperbolehkan mengajukan semacam syarat tertentu/ta'liq talaq, yang di dalamnya juga boleh memuat mengenai poligami. Dengan demikian, seorang istri dapat menjadikan alasan poligami sebagai tuntutan perceraian, jika dalam akad nikahnya tercantum syarat yang demikian ${ }^{35}$.

Turki telah memiliki aturan tentang poligami sebagaimana tertuang dalam The Turkish Family Law of Cyprus pasal 8-9,di dalamnya terdapat larangan melakukan perkawinan poligami selama pernikahan pertama masih berlangsung. Seorang suami tidak boleh melangsungkan perkawinan yang kedua, selama dia tidak mampu menunjukkan terputusnya ikatan pernikahan baik karena kematian, perceraian, atau pernyataan pembatalan. Dengan demikian, jika seorang suami melakukan pernikahan yang kedua padahal pernikahan pertama masih berlangsung, maka pernikahan keduanya dapat dibatalkan oleh pengadilan. Demikian pula, seorang istri boleh meminta ta'liq țalaq dengan mencantumkan poligami sebagai alasan perceraian ${ }^{36}$.

Mirip dengan Turki, Tunisia juga memiliki aturan tentang poligami yang menitikberatkan pada larangan poligami. Bahkan secara tegas, larangan poligami dicantumkan dengan disertai sanksi. Dalam The Code of The Personal Status Tunisia tahun 1958, dinyatakan bahwa: "Poligami dilarang. Bagi siapa saja baik bagi yang sudah menikah dan perkawinannya belum tuntas(cerai) kemudia mereka menikah lagi, maka ia akan dipenjara selama satu tahun atau denda 240.000 maims". Tegasnya, aturan Tunisia yang melarang poligami dilatarbelakangi oleh pemikiran bahwa syarat mutlak dalam poligami adalah kemampuan untuk berbuat adil. Sementara sikap adil adalah sesuatu yang tidak mungkin dicapai oleh manusia. Di sisi lain, para ahli hukum Tunisia berpandangan bahwa poligami -sebagaimana perbudakan- adalah 'institusi antara' yang boleh ada hanya pada fase perkembangan, dan tidak boleh ada lagi pada masyrakat yang telah berbudaya ${ }^{37}$.

Adapun Negara Syria dalam hal poligami memiliki aturan yang membolehkan poligami,hanya saja, kebolehan ini juga dilengkapi dengan syarat sang suami memiliki sumber nafkah yang cukup dan mampu berlaku adil. Untuk itu, poligami yang dilakukan harus melewati pengadilan agama

35 Nurul Ma'rifah, Pembaruan Hukum Keluarga Islam Yordania, dalam Khoiruddin Nasution, dkk., Hukum Perkawinan dan Warisan di Dunia Muslim Modern, (Yogyakarta: Academia, 2012), hlm. 73-75. 106-108.

${ }^{36}$ Umar Faruq Thohir, Reformasi Hukum Keluarga Islam Turki, dalam Ibid., hlm.

37 Siti Munadziroh, Pembaruan Hukum Keluarga di Tunisia, dalam Ibid., hlm. 5457. 
yang akan menilai dan menimbang apakah seseorang itu mampu dan layak melakukan poligami. Dalam hal ini, Undang-undang Syria tahun 1975 Pasal 17 menyatakan bahwa: "hakim mempunyai wewenag penuh untuk tidak mengizinkan seorang Suamiberistri lebih dari seorang jika terbukti tidak mampu berbuat adil dan tidak mampu menafkahinya"38.

Negara Iraq menetapkan aturan tentang poligami dalam The Iraki Law of Personal Status (ILPS) tahun 1959 pada pasal 3 ayat 4,5 dan 6. Ayat 4 menegaskan bahwa Poligami tidaklah diperbolehkan kecuali setelah mendapat izin dari pengadilan. Untuk mendapatkan izin poligami ini, pengadilan akan melihat tiga hal: kemampuan finasial, ada tidaknya kemaslahatan dalam poligami tersebut, dan kemampuan berbuat adil dari pelaku poligami. Jika syarat-syarat tersebut tidak dapat dipenuhi, maka pengadilan tidak akan menerbitkan izin poligami. Penilaian akan kelayakan poligami berdasarkan syarat di atas, diserahkan kepada hakim (qadli). Namun, Pada perkembangannya, muncul amandemen terhadap aturan poligami dengan ketentuan terbaru bahwa poligami dilarang, kecuali jika yang dipoligami adalah janda ${ }^{39}$.

Di Mesir, poligami termaktub dalam UU No. 100 tahun 1985. Secara prinsip poligami adalah boleh. Namun, UU No.100 tahun 1985 ini memberikan ketentuan bahwa suami yang poligami dapat dijadikan alasan perceraian yang diajukan pihak istri. Ini karena poligami dinilai dapat menimbulkan kesusahan dari sisi ekonomi. Di samping itu, pihak pengadilan harus pula memberitahukan rencana poligami seorang suami kepada istri atau istri-istrinya. Bila tidak, hal itu dapat dimasukkan sebagai tindakan pelanggaran hukum yang dapat dihukum dengan penjara maupun denda ${ }^{40}$.

Maroko juga membolehkan adanya poligami. Dalam UU Tahun 1958 disebutkan bahwa seorang istri berhak memasukkan persoalan poligami dalam ta'liq talaq-nya. Artiya, UU memberikan ruang kepada para istri untuk meminta cerai jika suami melakukan poligami. Di sisi lain, meski tidak masuk dalam ta'liq țalaq, pihak hakim atau pengadilan dapat pula memberikan pertimbangan apakah poligami yang akan dilakukan membawa manfaat atau justru sebaliknya. Hasil pertimbangan ini dapat menjadi penentu apakah poligami boleh dilaksanakan atau justru dilarang. Tambahan pula, seorang istri juga harus diberi tahu terlebih dahulu mengenai adanya rencana poligami ${ }^{41}$.Libya membolehkan poligami, dengan ketentuan praktek tersebut telah mendapat izin dari pengadilan. Izin pengadilan diberikan dengan mempertimbangkan tigahal pokok, yaitu kondisi sosial, kemampuan ekonomi, dan kondisi atau kemampuan fisik si suami ${ }^{42}$.

38 Masnun Tahir, Kebijakan Negara Terhadap Hak-Hak Perempuan Dalam Perkawinan (Studi Banding Atas Hukum Keluarga Syria dan Tunisia), dalam Ibid., hlm. 146.

\footnotetext{
${ }^{39}$ Juandi, Hukum Keluarga Muslim di Irak, dalam Ibid., hlm. 13.

${ }^{40}$ Khoiruddin Nasution, Op. Cit., hlm. 288-289.

${ }^{41}$ Ibid., hlm. 293-294.

42Ibid., hlm. 298.
} 


\section{HISTORISITAS DAN TUJUAN POLIGAMI: PERSPEKTIF INDONESIA DAN NEGARA MUSLIM MODERN}

Adapun Al Jazair juga memiliki UU perkawinan yang membolehkan adanya perkawinan poligami. Batas istri yang diperbolehkan adalah 4 orang. Namun demikian, praktek poligami yang dilakukan seorang suami dapat dijadikan alasan seorang istri untuk mengajukan perceraia, jika poligami tersebut tanpa sepengetahuan si istri ${ }^{43}$.Somalia juga menerapkan aturan yang membolehkan poligami secara bersyarat. Bagi mereka yang akan berpoligami harus mendapat izin dari pengadilan. Sedangkan alasan atau kriteria yang dapat membolehkan poligami adalah: istri mandul dengan bukti surat keterangan dokter, istri dipenjara lebih dari dua tahun, istri meninggalkan rumah tanpa izin lebih dari satu tahun, dank arena ada faktor kebutuhan sosial $^{44}$.

Bangladesh dan Pakistan juga memiliki aturan undang-undang yang membolehkan poligami. Namun demikian, sebagaimana sebagaimana negara muslim lainnya, poligami yang dilakukan harus seizin pengadilan. Pelanggaran akan ketentuan ini dapat dijatuhi hukuman penjara dan juga denda ${ }^{45}$.

\section{Tujuan Aturan Poligami}

Dapat dikatakan bahwa adanya pembaharuan hukum Islam termasuk hukum perkawinan dimana poligami merupakan salah satu bagiannya, adalah sebuah keniscayaan ${ }^{46}$. Wujud pembaharuan dimaksud salah satunya adalah adanya proses perubahan dan penguatan fikih dari yang semula bersifat volunter menjadi aturan baku berupa Undang-undang. Tujuannya, paling tidak ada tiga hal, yaitu ${ }^{47}$ :

a. Memberikan kepastian hukum khususnya berkenaan dengan masalah perkawinan, sebab sebelum adanya Undang-undang, aturan perkawinan bersifat judge made law.

b. Melindungi hak-hak kaum wanita dan sekaligus memenuhi keinginan dan harapan kaum wanita.

c. Menciptakan undang-undang yang sesuai dan relevan dengan konteks perkembangan zaman.

${ }^{43}$ Ibid.

${ }^{44}$ Ibid.

${ }^{45}$ Ibid., hlm. 290-291.

${ }^{46} \mathrm{Hal}$ ini mengingat banyaknya hal baru yang muncul seiring perkembangan dan dinamika kehidupan manusia yang tentu membawa persoalan-persoalan baru termasuk dalam bidang hukumnya. Di sisi lain, teks-teks yang menjadi sumber dan dasar penetapan hukum Islam juga membuka ruang untuk dilakuan ijtihad di dalamnya, termasuk dengan melakukan pemaknaan ulang terhadap teks hukum yang telah ada. Dalam hal ini, kiranya dapat dimunculkan kaidah; "Perubahan hukum (dapat terjadi) seiring dengan perubahan tempat, waktu, dan 'awaid (faktor-faktor lain, sosial misalnya)". Pada posisi inilah, energi ijtihad dengan segala perangkatnya, menjadi penting untuk terus dilakukan. Lihat, Abd. Salam Arif, Ijtihad, Perubahan Sosial dan Dinamika Hukum Islam, dalam Khoiruddin Nasution, dkk., Antologi Hukum Islam, (Yogyakarta: Pascasarjana Press, 2013), hlm. 31-37.

${ }^{47}$ Khoiruddin Nasution, Op. Cit., hlm. 40 
Tiga tujuan dari adanya pembaharuan dalam konteks hukum perkawinan di atas, kiranya juga merupakan tujuan adanya aturan tentang poligami. Memberikan kepastian hukum berarti bahwa dengan pola aturan poligami yang diatur oleh Undang-undang, para suami yang hendak poligami tidak boleh dan tidak dapat berbuat semaunya. Mereka harus tunduk dan patuh dengan ketentuan yang berlaku. Di dalam ketentuanketentuan ini, dimunculkan syarat-syarat yang menjamin keberlangsungan perkawinan, baik dengan istri yang sebelumnya maupun dengan istri yang baru termasuk dengan anak-anaknya. Mayoritas Negara yang membolehkan poligami mensyaratkan adanya izin dari pihak pengadilan untuk perkawinan poligami. Dalam proses perizinan inilah, Negara dapat melakukan intervensi dalam arti menetapkan syarat dan menimbang kelayakan orang yang hendak poligami. Dengan demikian, akan lebih tercipta kepastian hukum dalam konteks poligami.

Selanjutnya, aturan poligami juga merupakan wujud penghargaan hak-hak wanita, dimana yang demikian merupakan wujud keinginan kaum wanita untuk juga dihormati dan dihargai harkat dan martabatnya. Syarat kemampuan ekonomi dan fisik bagi pelaku poligami yang diterapkan di banyak Negara muslim merupakan bagian dari cerminan tujuan ini. Dengan kemampuan yang cukup baik fisik maupun finansial, seorang suami yang berpoligami diharapkan mampu tetap mensejahterakan istri-istri dan anakanaknya. Kemampuan ini penting, sebab jika ia tidak memiliki kemampuan yang cukup, tujuan rumah tangga yang hendak dituju tidak akan tercapai, dan sangat mungkin keluarga yang ada rentan akan berbagai persoalan.

Dalam batasan tujuan yang kedua pula, terlihat adanya aturan poligami yang menyaratkan adanya izin dari pihak istri. Ini dalam rangka menghargai hak seorang perempuan yang telah menjadi istri untuk dapat hidup berdampingan dengan suaminya secara utuh. Izin istri menjadi penting, karena dengan itu terlihat betapa suami telah berbuat maksimal untuk mendapatkan izin dimaksud.

Di samping itu, adanya syarat dapat berbuat adil juga dapat dinilai dalam rangka mewujudkan penghargaan kepada kaum wanita. Artinya, poligami yang dilakukan oleh seorang suami tidak boleh menjadi pintu masuk adanya kezaliman khusunya bagi istri sebelumnya. Di sinilah peran penting pengadilan untuk dapat menilai dan mempertimbangkan apakah seorang dapat berlaku adil jika melakukan perkawinan poligami. Jika tidak mampu berbuat adil, maka poligami ini justru dapat menjadi alasan pengajuan perceraian dari pihak istri, baik hal itu dituangkan dalam $t a^{\prime} l i q$ țalaq maupun tidak.

Selanjutnya, aturan poligami juga dapat dinilai dalam rangka menyesuaikan dengan konteks perkembangan zaman. Artinya, kondisi kekinian dalam sebuah Negara dapat pula menjadi pertimbangan dalam 


\section{HISTORISITAS DAN TUJUAN POLIGAMI: \\ PERSPEKTIF INDONESIA DAN NEGARA MUSLIM MODERN}

melahirkan aturan tentang poligami ${ }^{48}$. Hal ini terlihat dari adanya syaratsyarat poligami yang relatif lebih sulit dan kompleks jika dibandingkan dengan aturan dalam fikih klasik. Pemicunya antara lain perkembangan zaman yang secara sosiologis ditandai dengan meningkatnya peran serta kaum wanita dalam hampir semua lini kehidupan, sehingga membawa mereka kepada posisi dan peran yang hampir sama dengan kaum pria. Konsekwensinya, tuntutan persamaan hak dan kewajiban semakin mengemuka termasuk dalam ranah perkawinan dan khusunya poligami. Tunisia dan Turki adalah contoh dua Negara yang secara legal telah melakukan pelarangan terhadap praktek poligami dengan dasar pertimbangan bahwa poligami tidak lagi relevan untuk masyarakat modern yang telah berbudaya tinggi, di samping data faktual yang menunjukkan pelaku poligami hampir semuanya tidak mampu mewujudkan sikap yang adil dalam praktek perkawinan poligaminya.

\section{KESIMPULAN}

Paparan mengenai historisitas aturan poligami sebagaimana yang telah diuraikan dalam makalah ini, kiranya dapat diambil beberapa kesimpulan berikut ini. Pertama, poligami merupakan bagian dari kajian dalam hukum perkawinan, dan secara tekstual memang terdapat landasan hukum baik dari al-Qur'an maupun al Sunnah. Landasan tekstual ini lantas dipahami oleh para ulama dan menghasilkan pemahaman berupa seperangkat aturan yang dikenal sebagai Fikih. Dalam fikih ini, poligami dihukumi boleh, dengan jumlah istri maksimal empat orang. Secara normatif, syarat untuk mampu berlaku adil juga diberlakukan dalam perkawinan poligami. Kedua, seiring perjalanan waktu dan dinamika kehidupan di dalamnya, muncul tuntutan dari kalangan wanita untuk membuat aturan tentang perkawinan termasuk poligami yang lebih memberi kepastian hukum dan jaminan perlindungan harkat dan martabat kaum wanita. Dari sini, maka lahirlah UU tentang perkawinan dimana tercakup di dalamnya masalah poligami. Dalam konteks Indonesia, UU Perkawinan secara tegas menyebutkan asas perkawinan sebagai monogami. Namun, perkawinan poligami masih diizinkan, dengan maksimal empat orang istri. Hanya saja, UU perkawinan telah menetapkan serangkaian aturan 'tambahan' dalam rangka mewujudkan kepastian hukum dan penghargaan terhadap martabat kaum wanita. Hal ini dilakukan dengan aturan poligami yang harus melalui institusi Negara, dimana di dalamnya diterapkan syarat kebolehan poligami yang cukup ketat. Hal yang sama juga diterapkan di beberapa negara muslim modern, seperti Yordania, Mesir, dan Malaysia. Bahkan, Tunisia dan Turki melangkah lebih berani dengan menetapkan larangan poligami. Ketiga,

\footnotetext{
${ }^{48}$ Dalam batasan ini, misalnya sebuah Negara dapat pula menetapkan 'perubahan' aturan poligami dengan mempertimbangkan kondisi nasional sebuah Negara. Tentu hal ini idealnya telah dirumuskan secara matang oleh lembaga Negara yang berwenang. Lihat, Anwar Harjono, Hukum Islam Keluasan dan Keadiannya, (Jakarta: Bulan Bintang, 1987), hlm. 232-233
} 
HISTORISITAS DAN TUJUAN POLIGAMI:

PERSPEKTIF INDONESIA DAN NEGARA MUSLIM MODERN

tujuan adanya aturan poligami dalam bingkai Undang-undang adalah untuk memberikan kepastian hukum, memberikan penghargaan kepada Kaum wanita, dan dalam rangka mengkontekstualisasikan aturan hukum dengan kondisi kekinian, sehingga lebih relevan dan mampu mewujudkan kemaslahatan. 


\section{DAFTAR PUSTAKA}

Abd. Salam Arif, Ijtihad, Perubahan Sosial dan Dinamika Hukum Islam, dalam Khoiruddin Nasution, dkk., Antologi Hukum Islam, Yogyakarta: Pascasarjana Press, 2013

Abdul Wahab Khallaf, 'Ilm Ușül al-Fiqh, (Kuwait: Dar al ‘Ilm, 1978

Abdurahman, Kompilasi Hukum Islam, Jakarta: Akademika Pressindo, 2007

Abi Syuja', At-Taqrib, Ttp: Tnp, tt.

Anwar Harjono, Hukum Islam Keluasan dan Keadiannya, Jakarta: Bulan Bintang, 1987

As-Suyūti, Tanwīr al Hậwalik, Syarh 'al Muwattạ' Malik, Juz II, Ttp: Tnp, tt.

Bustanul Arifin, Pelembagaan Hukum Islam di Indonesia, Akar Sejarah, Hambatan dan Prospeknya. Jakarta: Gema Insani Press, 1996

Ibn Rusyd al-Qurtubī, Bidāyatul-Mujtahid wa Nihāyatul-Muqtasid, Juz II, Ttp: Dar Ihya' al Kutub al-'Arabiyyah, tt

Ibnu Hajar al-'Asqalanī, Bulūgh al Marām min Adillat al Ahkam, Ttp: Tnp, tt.

Izz ad Din Ibn 'Abd as-Salam, Qawa'id al-Ahkam fi Masalih al Anam, Jzz I, Beirut: Dar al-Kutub al-Ilmiyyah, 1999

Juandi, Hukum Keluarga Muslim di Irak, dalam Khoiruddin Nasution, dkk., Hukum Perkawinan dan Warisan di Dunia Muslim Modern, Yogyakarta: Academia, 2012.

Kementrian Agama RI, Al-Qur'an dan Tafsirnya, Jilid VII, Jakarta: Lentera Abadi, 2010

Khoiruddin Nasution, Hukum Perdata (Keluarga) Islam Indonesia dan Perbandingan Hukum Perkawinan di Dunia Muslim, Yogyakarta: ACAdeMIA\&Tazzafa, 2013

M. Ali Haidar, Nahdlatul Ulama dan Islam di Indonesia, Pendekatan Fikih dalam Politik, Jakarta: Gramedia, 1998

Marzuki Wahid dan Nurrohman, Dimensi Fundamentalisme dalam Politik Formalisasi Syari'at Islam, Kasus NAD, dalam Taswirul Afkar, Edisi No. 13 Tahun 2002

Masnun Tahir, Kebijakan Negara Terhadap Hak-Hak Perempuan Dalam Perkawinan (Studi Banding Atas Hukum Keluarga Syria dan Tunisia), dalam Khoiruddin Nasution, dkk., Hukum Perkawinan dan Warisan di Dunia Muslim Modern, Yogyakarta: Academia, 2012

Muhammad Ali Ash Shabuni, Tafsir Ayat al Ahkam min Al-Qur'an, Juz I, Ttp: Tnp, tt.

Muhammad Ibn Ismail Aṣ-Șan'ani, Subul as-Salām, Juz III, Surabaya: Al Hidayah, $\mathrm{tt}$.

Nurul Ma'rifah, Pembaruan Hukum Keluarga Islam Yordania, dalam Khoiruddin Nasution, dkk., Hukum Perkawinan dan Warisan di Dunia Muslim Modern, Yogyakarta: Academia, 2012.

Siti Munadziroh, Pembaruan Hukum Keluarga di Tunisia, dalam Khoiruddin Nasution, dkk., Hukum Perkawinan dan Warisan di Dunia Muslim Modern, Yogyakarta: Academia, 2012 
Umar Faruq Thohir, Reformasi Hukum Keluarga Islam Turki, dalam Khoiruddin Nasution, dkk., Hukum Perkawinan dan Warisan di Dunia Muslim Modern, Yogyakarta: Academia, 2012 